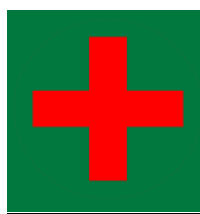

\title{
Karakteristik Pasien Demam Berdarah Dengue Rawat Inap di Rumah Sakit Umum UKI Tahun 2020
}

\author{
Diah Putri Ayu Islammia ${ }^{1}$, Nanda Aula Rumana ${ }^{2}$, Laela Indawati ${ }^{3}$, Deasy Rosmala \\ Dewi $^{4}$ \\ 1,2,3,4 Rekam Medis dan Informasi Kesehatan, Fakultas Ilmu-Ilmu Kesehatan, \\ Universitas Esa Unggul, DKI Jakarta, Indonesia \\ Email: ${ }^{1}$ diahputriayuislammia4366@gmail.com
}

\begin{abstract}
Dengue Hemorrhagic Fever (DHF) is an infectious disease caused by the dengue virus (DEN) which is spread through mosquito bites. This research is a quantitative descriptive study using a non-random sampling method with a saturated sample technique. The study was conducted at the UKI General Hospital with a sample of 94 patients. The results showed that the age of the most patients was 17-25 years, 30 patients (32\%), the most gender were male (60\%), domiciled in East Jakarta (70\%), the most occupations were self-employed (36\%), months The highest incidence was in March 23 patients, the most felt symptom was fever (100\%), the highest severity level based on the ICD-10 code was A97.0 94 patients (100\%), the category of platelet count when it arrived was abnormal (93\%), while the category of the number of platelets at home is normal (10\%), the category of the number of hematocrit is abnormal (43\%), while the category of the number of hematocrit when going home is normal (51\%), the ICD-10 code used is A91, the longest length of hospitalization was <6 days 67 patients (71\%). The condition when he returned home was healed (99\%).
\end{abstract}

Keywords: DHF, Characteristics, Dengue Hemorrhagic Fever

\begin{abstract}
Abstrak
Demam Berdarah Dengue (DBD) adalah penyakit menular yang disebabkan oleh virus dengue (DEN) yang ditularkan melalui gigitan nyamuk. Penelitian ini merupakan penelitian deskriptif kuantitatif dengan menggunakan metode non random sampling dengan teknik sampel jenuh. Penelitian dilakukan di Rumah Sakit Umum Daerah UKI dengan sampel 94 pasien. Hasil penelitian menunjukkan bahwa usia pasien terbanyak adalah 17-25 tahun, 30 pasien (32\%), jenis kelamin terbanyak adalah laki-laki (60\%), berdomisili di Jakarta Timur (70\%), pekerjaan terbanyak adalah wiraswasta ( $36 \%$ ), bulan Insiden tertinggi pada pasien 23 Maret, gejala yang paling dirasakan adalah demam (100\%), tingkat keparahan tertinggi berdasarkan kode ICD-10 adalah A97,0 94 pasien (100\%), kategori jumlah trombosit saat datang abnormal (93\%), sedangkan kategori jumlah trombosit di rumah normal (10\%), kategori jumlah hematokrit tidak normal (43\%), sedangkan kategori jumlah hematokrit saat pulang normal (51\%), kode
\end{abstract}


ICD-10 yang digunakan adalah A91, lama rawat inap terlama $<6$ hari 67 pasien $(71 \%)$. Kondisi saat pulang sudah sembuh (99\%).

Kata kunci: DBD, Ciri-ciri, Demam Berdarah Dengue

\section{PENDAHULUAN}

Rekam medis adalah dokumen yang memuat catatan dan dokumen yang berisikan tentang identitas pasien, pemeriksaan, pengobatan, tindakan, dan pelayanan yang telah diberikan kepada pasien. Rekam medis harus tertulis, lengkap dan jelas (Handayani \& Feoh, 2016)

Penyakit Demam Berdarah Dengue (DBD) merupakan penyakit infeksi yang disebabkan oleh virus dengue. Virus dengue ditularkan oleh nyamuk Aedes aegypti dan Aedes albopictus. Penyakit yang disebabkan oleh nyamuk antara lain chikungunya, demam kuning, dan infeksi virus Zika. Virus dengue menyebar di daerah tropis dan dipengaruhi oleh curah hujan, suhu dan urbanisasi yang cepat (WHO,2016). Penyakit ini ditandai dengan demam mendadak selama 2 sampai 7 hari tanpa sebab yang jelas, lemas / mengantuk, gelisah, mulas, dan tanda-tanda kulit berdarah berupa bercak berdarah. Kadang mimisan, disentri, muntah darah, kesadaran menurun bahkan syok (Kemenkes RI, 2020). Demam berdarah dengue disebabkan oleh virus dengue dari genus Flaviviridae dan Flavivirus. Virus ini memiliki empat serotipe, yaitu DEN-1, DEN-2, DEN-3, dan DEN-4. Saat menyerang manusia, keempat serotipe tersebut menimbulkan gejala yang berbeda-beda sehingga menimbulkan infeksi paling serius di Indonesia yaitu DEN-3. Demam berdarah dengue tidak menular melalui kontak langsung dengan manusia, dan virus dengue yang menjadi penyebab demam berdarah hanya dapat ditularkan melalui nyamuk. Oleh karena itu, penyakit ini termasuk dalam kelompok penyakit yang ditularkan oleh arthropoda. Virus hanya dapat bertahan hidup di dalam sel yang hidup. Oleh karena itu, untuk bertahan hidup, virus harus bersaing dengan sel manusia yang ditempati terutama untuk kebutuhan protein. Jika sistem kekebalan tubuh seseorang yang terinfeksi virus tersebut melemah, akibatnya akan semakin merusak sel-sel jaringan tersebut. Sebaliknya jika sel-selnya berkembang pesat maka organ-organ tersebut akan berfungsi dengan baik, sembuh, dan kebal terhadap virus dengue yang masuk ke dalam tubuh (Egziabher \& Edwards, 2013).

Penelitian Sihite tentang karakteristik penderita DBD yang dirawat di RSUD Medan H. Adam Malik tahun 2012 menemukan proporsi penderita tertinggi pada kelompok umur 16-20 dan 21-25 tahun (Sihite, 2016). Pada tahun 2016, Kementerian Kesehatan RI juga mencatat jumlah penderita DBD di Indonesia dari Januari hingga Februari.Ada 8.487 kasus DBD, 108 diantaranya meninggal dunia. Di Indonesia penduduk usia 5-14 tahun terbanyak yang mengalami DBD mencapai 43,44\%, sedangkan yang berusia 15-44 tahun mencapai 33,25\% (Kemenkes RI, 2016).

Hasil penelitian Lisa di RS Arifin Achmad Provinsi Riau menunjukkan kelompok umur tertua adalah 15-19 tahun sebanyak 16 orang (34,8\%) (Lisa, 2013). Sementara itu, penelitian Khoirun terhadap pasien DBD yang dirawat di RSUD Lubuk Pakam menunjukkan bahwa 138 pasien tertinggi berusia $\geq 15$ tahun (63\%) (Khoirun, 2012). 
Dalam penelitian yang dilakukan Alam di RSUP Sanglah, antara tahun 2013 hingga 2014, ditemukan bahwa 51,9\% penderita DBD berusia antara 5-10 tahun. Dibandingkan dengan lansia, penderita infeksi dengue paling sering menyerang orang di bawah usia 15 tahun. Umur 5-10 tahun adalah waktu untuk bersekolah, Sekolah merupakan tempat paling banyak terjangkit penyakit DBD, karena sekolah merupakan tempat berkumpulnya orang-orang dari berbagai daerah (Alam, 2016).

Berdasarkan penelitian sebelumnya yang dilakukan oleh Jefri S pada tahun 2013, jumlah penderita DBD di Rumah Sakit Umum Pusat Adam Malik Kota Medan sebanyak 110 anak. Distribusi proporsi balita dengan DBD adalah 10-14 tahun (37,3\%), jenis kelamin perempuan $(58,2 \%)$, bulan paling sering rawatan pada Desember 2011 $(16,2 \%)$ dan Desember 2012 (19\%), menghasilkan kesembuhan 93,6\%, dan dari tahun 2011 sampai 2012 prevalensi DBD menurun dari 68 menjadi 42 (Jefri, 2013).

Berdasarkan penjelasan pada latar belakang tersebut, maka dapat dirumuskan masalah penelitian ini adalah bagaimanakah karakteristik pasien Demam Berdarah Dengue Rawat Inap di Rumah Sakit Umum UKI tahun 2020?. Adapun tujuan penelitian ini adalah untuk mengetahui karakteristik pasien Demam Berdarah Dengue rawat inap di Rumah Sakit Umum UKI.

\section{METODE}

Metodelogi penelitian yang digunakan yaitu metode deskriptif yang bersifat kuantitatif yang bertujuan untuk mengetahui karakteristik Pasien Demam Berdarah Dengue rawat inap di Rumah Sakit Umum UKI yang terdiri dari usia, jenis kelamin, domisili, pekerjaan, bulan kejadian, gejala, tingkat keparahan, trombosit saat datang dan pulang, hematokrit saat datang dan pulang, kode ICD-10, lama waktu rawat inap, keadaan sewaktu pulang. Populasi dalam penelitian ini adalah rekam medis pasien Demam Berdarah Dengue rawat inap di Rumah Sakit Umum UKI pada tahun 2020 dengan jumlah 94 pasien. Teknik pengumpulan sampel pada penelitian ini dilakukan dengan teknik pengumpulan secara non random dengan demikian penggunaan seluruh populasi tanpa harus menarik sampel penelitian sebagai unit observasi disebut sebagai teknik sensus, dengan menggunakan perhitungan statistical product and service solutions (SPSS).

\section{HASIL}

Tabel 1. Kategori Karakteristik Pasien Demam Berdarah Dengue di Rumah Sakit Umum UKI Tahun 2020

\begin{tabular}{ccc}
\hline Variabel & Jumlah (N) & Presentase (\%) \\
\hline Usia & & \\
\hline 0-5 Tahun & 2 & $2 \%$ \\
\hline 6-11 Tahun & 7 & $7 \%$ \\
\hline 12-16 Tahun & 12 & $13 \%$ \\
\hline 17-25 Tahun & 30 & $32 \%$ \\
\hline 26-35 Tahun & 24 & $26 \%$ \\
\hline
\end{tabular}




\begin{tabular}{|c|c|c|}
\hline 36-45 Tahun & 7 & $7 \%$ \\
\hline 46-55 Tahun & 3 & $3 \%$ \\
\hline 56-65 Tahun & 7 & $7 \%$ \\
\hline$>65$ Tahun & 2 & $2 \%$ \\
\hline \multicolumn{3}{|l|}{ Jenis Kelamin } \\
\hline Laki-Laki & 56 & $60 \%$ \\
\hline Perempuan & 38 & $40 \%$ \\
\hline \multicolumn{3}{|l|}{ Domisili } \\
\hline Jakarta Utara & 1 & $1 \%$ \\
\hline Jakarta Barat & 2 & $2 \%$ \\
\hline Jakarta Pusat & 2 & $2 \%$ \\
\hline Jakarta Selatan & 6 & $6 \%$ \\
\hline Luar Jakarta & 17 & $18 \%$ \\
\hline Jakarta Timur & 66 & $70 \%$ \\
\hline \multicolumn{3}{|l|}{ Pekerjaan } \\
\hline Ibu rumah tangga & 5 & $5 \%$ \\
\hline PNS & 6 & $6 \%$ \\
\hline Dibawah umur & 7 & $7 \%$ \\
\hline Mahasiswa & 17 & $18 \%$ \\
\hline Pelajar & 25 & $27 \%$ \\
\hline Wiraswasta & 34 & $36 \%$ \\
\hline \multicolumn{3}{|l|}{ Tingkat Keparahan } \\
\hline A97.0 & 94 & $100 \%$ \\
\hline A97.1 & 0 & $0 \%$ \\
\hline A97.2 & 0 & $0 \%$ \\
\hline A97.9 & 0 & $0 \%$ \\
\hline
\end{tabular}

\begin{tabular}{ccc}
\hline Variabel & Jumlah (N) & Presentase (\%) \\
\hline Trombosit saat datang & & $7 \%$ \\
\hline Normal & 7 & $93 \%$ \\
\hline Tidak Normal & 87 & $10 \%$ \\
\hline Trombosit saat pulang & & $90 \%$ \\
\hline Normal & 9 & \\
\hline Tidak Normal & 85 & $57 \%$ \\
\hline Hematokrit saat datang & & $43 \%$ \\
\hline Normal & 54 & $51 \%$ \\
\hline Tidak Normal & 40 & $49 \%$ \\
\hline Hematokrit saat pulang & & \\
\hline Normal & 48 & $71 \%$ \\
\hline Tidak Normal & 46 & $28 \%$ \\
\hline lama waktu rawat inap & & \\
\hline$<6$ Hari & 67 & \\
\hline 6-9 Hari & 26 & \\
\hline
\end{tabular}




\begin{tabular}{ccc}
\hline$>9$ Hari & 1 & $1 \%$ \\
\hline Keadaan sewaktu pulang & & \\
\hline Sembuh & 93 & $99 \%$ \\
\hline $\begin{array}{c}\text { Pulang atas permintaan } \\
\text { sendiri }\end{array}$ & 1 & $1 \%$ \\
\hline Pindah rumah sakit & 0 & $0 \%$ \\
\hline Meninggal & 0 & $0 \%$ \\
\hline
\end{tabular}

Tabel 1 menunjukan usia pasien Demam Berdarah Dengue Tahun 2020 terbanyak berumur 17-25 tahun 30 pasien (32\%), jenis kelamin terbanyak adalah laki-laki 56 pasien (60\%), domisili terbanyak pasien DBD ada pada wilayah Jakarta Timur 66 pasin (70\%), pekerjaan terbanyak adalah wiraswasta 34 pasien (36\%), tingkat keparahan terbanyak berdasarkan kode ICD-10 adalah A97.0 94 pasien (100\%), kategori trombosit saat datang terbanyak dalam keadaan tidak normal 87 pasien (93\%), kategori trombosit saat pulang terbanyak dalam keadaan tidak normal 85 pasien $(90 \%)$, kategori hematokrit terbanyak saat datang dalam keadaan normal 54 pasien $(57 \%)$, kategori hematokrit terbanyak saat pulang dalam keadaan normal 48 pasien (51\%), lama waktu rawat inap terbanyak <6 hari 67 pasien $(71 \%)$, dan keadaan sewaktu pulang terbanyak adalah dalam keadaan sembuh 93 pasien $(99 \%)$

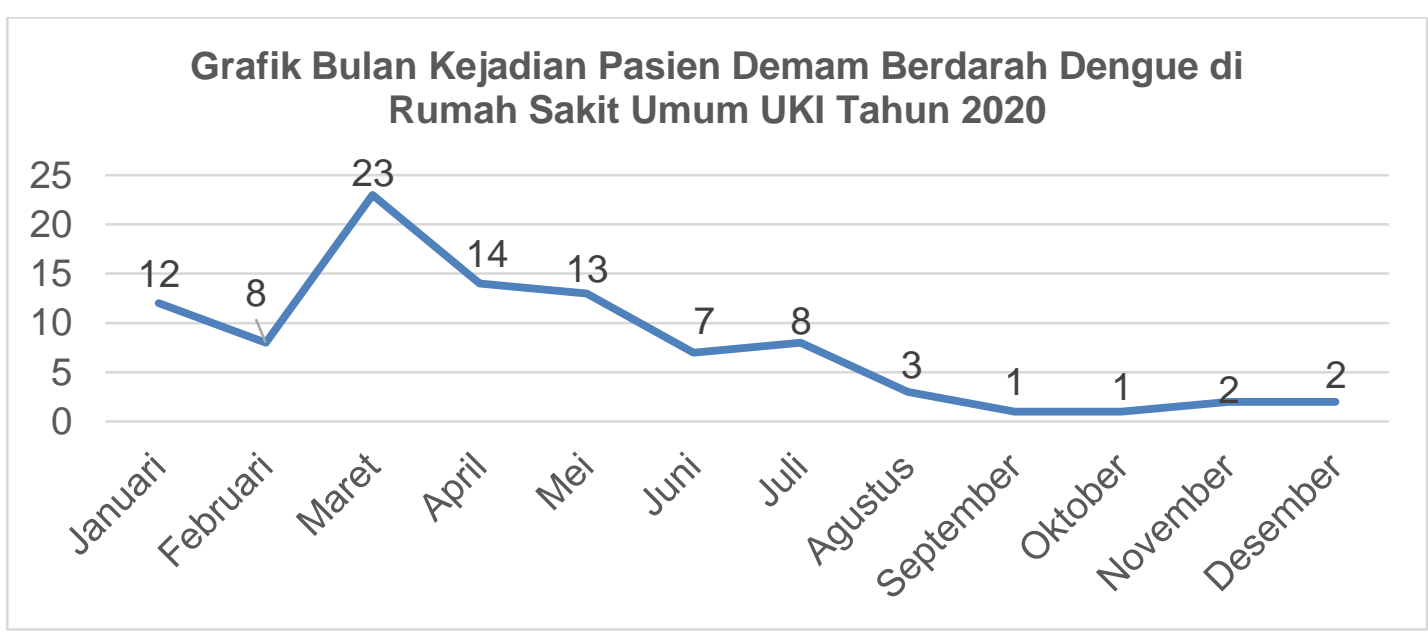

Gambar 1. bulan kejadian pasien Demam Berdarah

Dengue di Rumah Sakit Umum UKI Tahun 2020

Berdasarkan gambar 1 diatas, dapat dilihat bahwa bulan kejadian tertinggi pada pasien DBD di Rumah Sakit Umum UKI adalah bulan Maret 23 pasien, April 14 pasien, Mei 13 pasien, Janurai 12 pasien, Februari dan Juli 8 pasien, Agustus 3 pasien, November dan Desember 2 pasien, dan yang terendah pada bulan September dan Oktober 1 pasien. 


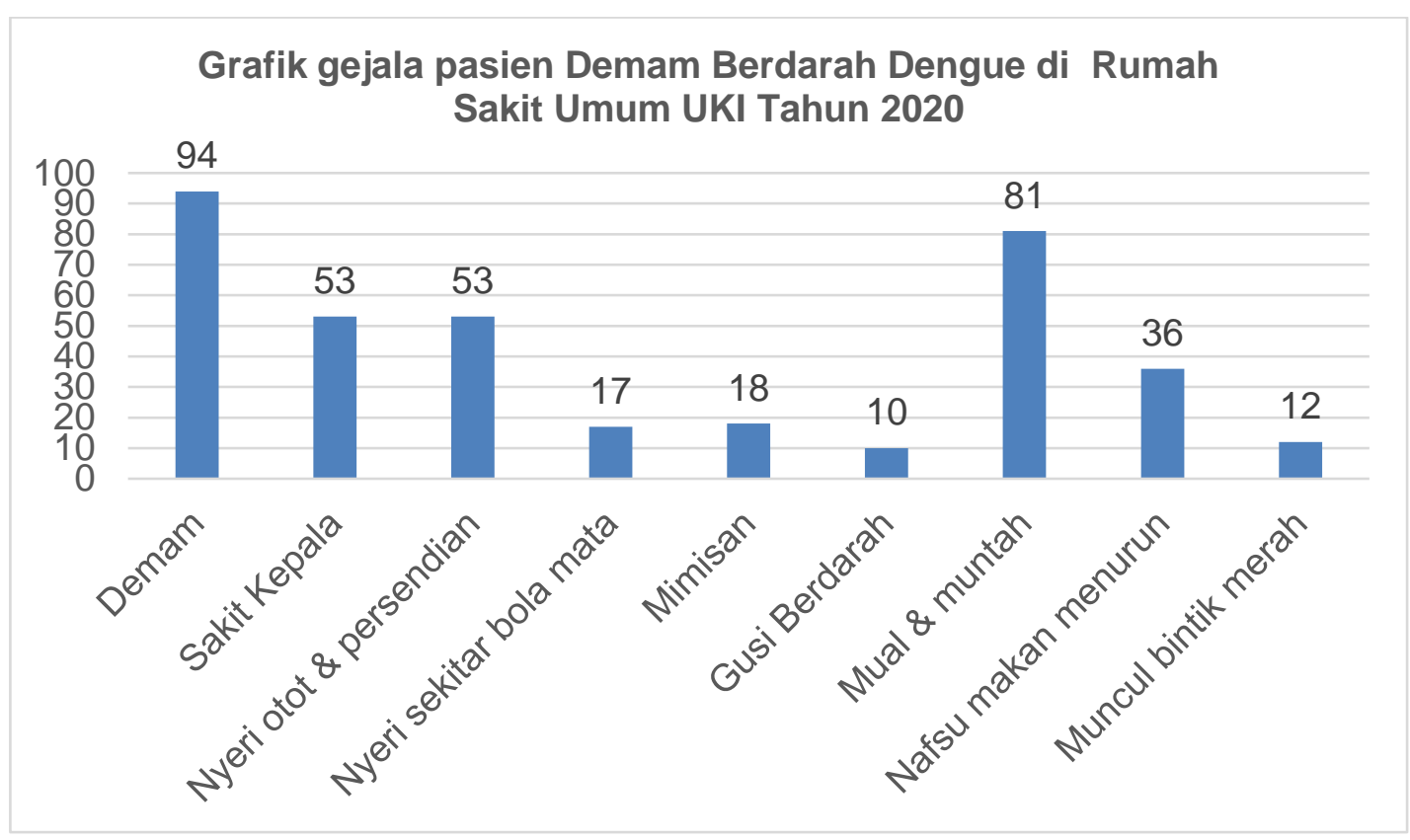

Gambar 2. Gejala pasien Demam Berdarah Dengue di Rumah Sakit Umum UKI Tahun 2020

Berdasarkan gambar 2 diatas, dapat dilihat bahwa gejala pasien Dbd di Rumah Sakit Umum UKI terbanyak adalah demam 94 pasien, mual dan muntah 81 pasien, sakit kepala, nyeri otot dan persendian 53 pasien, nafsu makan menurun 36 pasien, mimisan 18 pasien, nyeri sekitar bola mata 17 pasien, muncul bintik merah 12 pasien, dan yang paling sedikit adalah gusi berdarah 10 pasien.

Dalam penelitian yang dilakukan terhadap 94 rekam medis pasien Demam Berdarah Dengue di Rumah Sakit Umum UKI tahun 2020, berdasarkan kode ICD-10 yang digunakan dalam mengoding pasien Demam Berdarah Dengue seluruhnya memakai kode A91.

\section{PEMBAHASAN}

Berdasarkan penelitian yang telah dilakukan terhadap 94 pasien, diketahui bahwa kategori usia terbanyak adalah 17-25 tahun 30 pasien (32\%). Hasil ini sesuai dengan penelitian yang dilakukan oleh Kurniasary di RS Universitas Hasanuddin dimana didapatkan 30 pasien $(65,21 \%)$ pada usia $17-25$ tahun. Hal ini kemungkinan dikarenakan golongan usia tersebut merupakan golongan usia remaja akhir yang cenderung lebih produktif dan aktif, serta memiliki banyak kegiatan tambahan di luar rumah sehingga lebih berisiko untuk tergigit nyamuk Aedes aegypti (Kurniasary, 2016).

Untuk karakteristik berdasarkan jenis kelamin pasien, kebanyakan berjenis kelamin laki-laki berjumlah 56 pasien $(60 \%)$ dan terendah adalah perempuan berjumlah 38 pasien (40\%). Memperlihatkan bahwa penderita laki-laki lebih banyak dibandingkan perempuan, hal tersebut dipengaruhi karena pada umumnya laki-laki akan lebih rentan terhadap penyakit Demam Berdarah Dengue dibanding perempuan karena perempuan lebih mudah dalam memproduksi imonuglobulin dan antibodi yang dikelola secara 
genetika dan hormonal, dan laki-laki lebih banyak beraktifitas di luar rumah (Irma, 2019). Perempuan lebih mudah dalam memproduksi imonuglobulin dan antibody, dikarenakan pada perempuan telah diproduksi hormon estrogen yaitu hormon yang berperan penting dalam perkembangan dan pertumbuhan karakteristik seksual wanita serta proses reproduksinya, sehingga menyebabkan perempuan lebih kebal terhadap terjadinya infeksi (Pujiwidodo, 2016)

Untuk karakteristik berdasarkan domisili, pasien terbanyak adalah Jakarta Timur berjumlah 66 pasien (70\%). karena Rumah Sakit Umum UKI berada di daerah Jakarta timur berpengaruh pada domisili pasien rawat inap terbanyak Jakarta timur. Hal tersebut di pengaruhi karena pada umumnya DKI Jakarta merupakan salah satu wilayah dengan kepadatan penduduk tertinggi di Indonesia dan merupakan wilayah yang sangat padat aktivitasnya. Perlu diketahui bahwa, resiko penularan penyakit DBD menjadi lebih tinggi pada wilayah Jakarta timur dengan kepadatan penduduk tertinggi. Oleh sebab itu, dapat dikatakan bahwa wilayah Jakarta timur memiliki resiko penularan penyakit DBD yang tinggi (Nandini \& Susilowati, 2017).

. Hal ini diperkuat dengan data yang menunjukkan bahwa wilayah DKI Jakarta dengan jumlah penduduk mencapai 11.058.944 serta jumlah penduduk paling banyak adalah Jakarta Timur mencapai 2.318.639 penduduk (Direktorat, Jenderal Kependudukan dan Pencatatan Sipil, 2020)

Untuk karaktersitik berdasarkan pekerjaan terbanyak adalah wiraswasta dengan jumlah 34 pasien (36\%). Dalam hal ini berkaitan dengan kategori umur sebelumnya yaitu kategori remaja akhir, sehingga jumlah penderita Demam Berdarah Dengue terbesar ditemukan pada kategori pekerjaan sebagai wiraswasta yang rata-rata memililki umur diatas 15 tahun (Velasquez-Valencia dkk, 2018) Hal ini juga terkait dengan kebiasaan nyamuk Aedes aegypti yang hidup di lingkungan pabrik atau kantoran yang kurang bersih sehingga menjadi tempat perindukan nyamuk ataupun tempat-tempat umum sebagai tempat wiraswasta beraktivitas (Sinurat, 2017).

Berdasarkan penelitian yang telah dilakukan terhadap 94 pasien diketahui bahwa tingkat keparahan berdasarkan kode ICD-10 pasien Demam Berdarah Dengue di rumah sakit umum UKI tahun 2020 terbanyak adalah A97.0 94 pasien (100\%) adalah Demam Berdarah Dengue tanpa tanda-tanda peringatan, termasuk Demam Berdarah Dengue tingkat 1 dan 2 (WHO, 2016). Hasil yang sama di peroleh di RSUP Sanggalah bulan Juli-Desember tahun 2014 didapatkan jumlah penderita DBD terbesar terdapat pada tingkat keparahan DBD derajat I yaitu 56,3\%. Hasil penelitian ini terkait dengan tingkat pengetahuan pasien dalam menyadari gejala-gejala yang timbul dalam infeksi DBD, sehingga berpengaruh terhadap tingkat keparahan saat diagnosis DBD ditegakan (Anindya dkk, 2018).

Untuk karakteristik berdasarkan jumlah trombosit saat datang dan pulang pasien Demam Berdarah Dengue di Rumah Sakit Umum UKI tahun 2020. Kategori jumlah trombosit saat datang kerumah sakit dalam keadaan normal berjumlah 7 pasien (7\%) dan yang tidak normal berjumlah 87 pasien (93\%). Berdasarkan hasil penelitian, yang dilakukan oleh Amrina Rasyada, Ellyza Nasrul, Zulkarnain Edward secara keseluruhan jumlah trombosit di bawah normal $<100.000 / \mu 1$ (trombositopenia) sebanyak 100\% (Rasyada dkk, 2014). Dan jumlah trombosit pasien pulang terbanyak adalah dalam keadan normal berjumlah 9 pasien (10\%) dan dalam kedaan tidak normal berjumlah 85 
pasien (90\%). Hal ini menunjukkan bahwa belum semua penderita DBD memiliki jumlah trombosit normal sehingga boleh pulang, tetapi masih ada 56,7\% yang masih memiliki trombosit tidak normal $<150.000 / \mu 1$, mereka diizinkan pulang karena sudah menunjukkan adanya perbaikan dengan trombosit yang sudah mengalami kenaikan dari yang sebelumnya (Ketaren, 2009).

Untuk karakteristik berdasarkan jumlah hematokrit saat datang dan pulang pasien Demam Berdarah Dengue di Rumah Sakit Umum UKI tahun 2020. Kategori jumlah hematokrit pasien datang dalam keadan normal berjumlah 54 pasien $(57 \%)$ dan yang tidak normal berjumlah 40 pasien $(40 \%)$ Berdasarkan penelitian yang dilakukan oleh Wardhy Arief Hidayat, Rismawati Yaswir, Arina Widya Murni didapatkan bahwa 31,9\% penderita DBD mengalami hemokonsentrasi, sedangkan penderita DBD yang memiliki nilai hematokrit normal saat masuk rumah sakit sebanyak 54,4\%. Hal tesebut menunjukan bahwa banyak pasien DBD yang memiliki nilai hematokrit normal bahkan rendah dan didiagnosis DBD (Hidayat dkk, 2017). Dan jumlah Hematokrit pasien pulang Demam Berdarah Dengue dari Rumah Sakit Umum UKI dalam keadan normal berjumlah 48 pasien $(51 \%)$ dan yang tidak normal berjumlah 46 pasien (49\%). Dalam penelitian ini diketahui proporsi hematokrit penderita pada saat pulang rumah sakit dalam keadaan normal sebanyak $93,5 \%$ dan dalam keadaan tidak normal sebanyak $6,5 \%$. Hal ini dipengaruhi oleh penggantian volume tubuh yaitu sejak pasien masuk rumah sakit, dan juga dilihat dari hasil pemeriksaan laboratorium, pasien diizinkan pulang dengan jumlah hematokrit dalam keadaan normal (Sinurat, 2017).

Untuk karakteristik lama waktu rawat inap yang telah dilakukan terhadap 94 pasien Demam Berdarah Dengue di Rumah Sakit Umum UKI tahun 2020, diketahui lawa waktu rawat inap pasien Demam Berdarah Dengue terbanyak adalah $<6$ hari 67 pasien $71 \%$, pada lama waktu rawat inap tersebut belum masuk dalam standar ideal lama hari rawat. Hal ini karena demam turun lebih cepat pada pasien DBD yang dirawat inap, sehingga diperbolehkan pulang (Cahyani, 2020).

Berdasarkan penelitian yang telah dilakukan terhadap 94 pasien Dema Berdarah Dengue di Rumah Sakit Umum UKI tahun 2020ndiketahui keadaan sewaktu pulang pasien DBD terbanyak adalah pasien dalam keadaan sembuh 93 pasien (99\%), pulang atas permintaan sendiri 1 pasien (1\%), tidak ada pasien yang pindah rumah sakit dan meninggal 0 pasien (0\%), Berdasarkan hasil penelitian yang dilakukan di Rumah Sakit Roemani Semarang, keadaan saat pulang pasien Demam Berdarah Dengue periode 1 Januari 2011 sampai 31 Juni 2011 didapatkan hasil pasien DBD pulang dengan keadaan sembuh 96,5\%, pulang atas permintaan sendiri 3,5\% dan meninggal 0\% (Nisa, 2011).

Untuk karaktersitik berdasarkan bulan kejadian terbanyak pada bulan Maret 23 pasien $(25 \%)$. Hal tersebut dipengaruhi karna perubahan musim hujan. analisis curah hujan pada bulan Maret 2020 menunjukkan bahwa sebanyak $68.2 \%$ wilayah Indonesia mengalami curah hujan kategori menengah, kemudian $28.05 \%$ mengalami curah hujan kategori tinggi hingga sangat tinggi, sedangkan analisis sifat hujan pada bulan Maret 2020 menunjukkan bahwa sebanyak $34.06 \%$ wilayah Indonesia mengalami sifat hujan Atas Normal (AN), 33.04\% (BMKG, 2020). Menurut penelitian Rossa Dwi Wahyuni, M.Sabir tahun 2011 diperoleh presentase tertinggi yaitu pada bulan Maret yaitu sebanyak 28 orang (13,7\%), namun pada bulan-bulan yang lain jumlah kasus penderita demam berdarah dengue tidak beda jauh. Hasil penelitian ini mendukung teori yang mengatakan bahwa perubahan musim hujan mempengaruhi frekuensi gigitan 
nyamuk. Puncak gigitan terjadi pada siang dan sore hari. Penyakit demam berdarah dengue ini menunjukan keberadaannya sepanjang tahun penyakit ini sangat dipengaruhi oleh kondisi-kondisi lingkungan yang memungkinkan nyamuk untuk berkembang biak dan berpotensi untuk melakukan kontak dengan manusia dan menularkan penyakit. Curah hujan dan tingkat kelembaban yang tinggi diikuti dengan bertambahnnya jumlah penderita demam berdarah demikian juga sebaliknya curah hujan rendah maka jumlah penderita demam berdarah dengue mengalami penurunan. Hal ini menunjukan bahwa curah hujan mempengaruhi jumlah kasus demam berdarah dengue (Wahyuni \& Sabir, 2011).

Berdasarkan penelitian yang telah dilakukan terhadap 94 pasien, diketahui bahwa gejala pasien Demam Berdarah Dengue di Rumah Sakit Umum UKI tahun 2020 terbanyak adalah demam 94 pasien. Pada infeksi Demam Berdarah Dengue, gejala klinis yang muncul sangat berfariasi sehingga diagnosis klinis awal Demam Berdarah Dengue sering sulit ditegakkan. Gejala klinis yang paling dominan muncul adalah demam. Demam merupakan respon dari pertahanan tubuh terhadap serangan virus Dengue. Selain demam, 50\% penderita mengalami mual dan muntah (Wila \& Nisa, 2020).

A97.0 Demam Berdarah Dengue tanpa tanda-tanda peringatan, termasuk Demam Berdarah Dengue tingkat 1 dan 2. A97.1 Demam Berdarah Dengue dengan tanda peringatan klinis seperti sakit perut atau nyeri tekanan, pendarahan, lesu atau gelisah, penurunan jumlah trombosit yang cepat, peningkatan hematocrit, tanda-tanda lain dapat mencakup muntah terus-menerus, akumulasi cairan terlihat, pembesaran hati lebih dari $2 \mathrm{~cm}$. A97.2 Demam Berdarah Dengue parah, tanda-tanda klinis meliputi kebocoran plasma yang parah menyebabkan sindrom syok dengue atau akumulasi cairan dengan gangguan pernapasan, perdarahan hebat seperti yang dievaluasi oleh dokter; keterlibatan organ yang parah, hati aspartat transaminase atau alanine aminotransferase 21000, gangguan kesadaran (ensefalitis), keterlibatan organ lain seperti miokarditis atau nefritis. A97.9 Demam Berdarah Dengue tanpa di jelaskan tanda-tanda atau gejalanya (18). Tetapi hasil penelitian dari 94 rekam medis berdasarkan kode ICD-10 pasien Demam Berdarah Dengue di Rumah Sakit Umum UKI tahun 2020 seluruhnya masih memakai kode ICD-10 versi 2010 yaitu A91. Hal ini berdasarkan rekam medis pasien rawat inap di Runah Sakit Kristen Lindi Mara tahun 2018, total keseluruhan diagnosis utama sebanyak 252, dengan diagnosis utama terbanyak berdasarkan ICD-10 adalah Dengue Haemorrhagic Fever atau yang lebih dikenal Demam Berdarah Dengue dengan kode A91 (Nasution \& Septia, 2020)

\section{KESIMPULAN DAN SARAN}

Usia pasien terbanyak adalah 17-25 tahun 30 pasien (32\%), jenis kelamin terbanyak laki-laki 56 pasien (60\%), domisili terbanyak pasien DBD ada di wilayah Jakarta Timur 66 pasien (70\%), pekerjaan terbanyak adalah wiraswasta 34 pasien (36\%), tingkat keparahan berdasarkan ICD-10 terbanyak adalah A97.0 94 pasien $(100 \%)$, kategori jumlah trombosit saat datang terbanyak dalam keadaan tidak normal 87 pasien (93\%), kategori jumlah trombosit saat pulang terbanyak dalam keadaan tidak normal 85 pasien $(90 \%)$, kategori jumlah hematokrit saat datang terbanyak dalam keadaan normal 54 pasien (57\%), kategori jumlah hematokrit saat pulang terbanyak dalam keadaan normal 48 pasien (51\%), lama waktu rawat inap pasien terbanyak adalah 
$<6$ hari 67 pasien (71\%), keadaan sewaktu pulang terbanyak dalam keadaan sembuh 93 pasien (99\%), bulan kejadian pasien DBD terbanyak pada bulan Maret 23 pasien (25\%), gejala pasien DDBD terbanyak adalah demam 94 pasien (100\%), kode ICD-10 pasien Demam Berdarah Dengue dari 94 pasien memakai A91.

Disarankan Rumah Sakit Umum UKI menggunakan ICD-10 terbaru versi 2016 agar mengetahui tingkat keparahan pasien Demam Berdarah Dengue berdasarkan kode ICD-10.

\section{DAFTAR PUSTAKA}

Handayani T, Feoh G. Perancangan Sistem Informasi Rekam Medis Berbasis Web (Studi Kasus Di Klinik Bersalin Sriati Kota Sungai Penuh - Jambi). J Teknol Inf dan Komput. 2016;2(2):226-36.

WHO. Sebaran Kejadian Demam Berdarah Dengue Di Kota Manado Tahun 2016-2018. 2016;

Kemenkes RI. No Ti. 2020;

Egziabher TBG, Edwards S. Analisis Faktor Yang Mempengaruhi Kejadian Demam Berdarah Dengue (DBD) Di Wilayah Endemis Landungsari Kabupaten Malang. Africa's potential Ecol Intensif Agric. 2013;53(9):1689-99.

Sihite. Karakteristik Penderita Demam Berdarah Dengue yang Dirawat Inap di RSUD Dr.Pirngadi Kota Medan Tahun 2016. 2013;

Kemenkes RI. No Title. 2016;

Lisa. Karakteristik Pasien Demam Berdarah Dengue Di Rumah Sakit Umum Haji Medan Periode Januari-Desember 2015. 2013;

Khoirun. No Titl. 2012;

Alam. Karakteristik pasien anak dengan infeksi dengue di RSUP Sanglah tahun 20132014. Medicina (B Aires). 2016;47(2):158-62.

Jefri. Karakteristik Pasien Demam Berdarah Dengue Di Rumah Sakit Umum Haji Medan Periode Januari-Desemeber 2015. 2013;

Kurniasary. Karakteistik Pasien Demam Berdarah Dengue Yang Menjalani Rawat Inap Di RS Universitas Hasanuddin Tahun 2014-2015. 2016;

Irma. Hubungan Nilai Hematokrit Terhadap Jumlah Trombosit Pada Penderita Demam Berdarah Dengu yang Dirawat Inap di RSUP H. Adam Malik Medan. 2019;1(1):41-57. Available from: http://www.ghbook.ir/index.php?name= \&option $=$ com_dbook\&task=readonline\&book_id=13650\&page $=73 \&$ chkhashk $=\mathrm{E}$ D9C9491B4\&Itemid=218\&lang=fa\&tmpl=component\%0Ahttp://www.albayan.a e\%0Ahttps://scholar.google.co.id/scholar?hl=en\&q=APLIKASI+PENGENA

Pujiwidodo D. Karakteristik Pasien Demam Berdarah Dengue Pada anak Di RSUD Indramayu Pada Tahun 2015. 2016;III(2):2016.

Nandini DM, Susilowati MHDW. Perbandingan Wilayah Penyakit Demam Berdarah Dengue ( DBD ) di Jakarta Tahun 2005 - 2015. J IRONS. 2017;8:435-43.

Direktorat, Jenderal Kependudukan dan Pencatatan Sipil. Buku Data Statistik Sektoral Provinsi DKI Jakarta Tahun 2020. 2020;

Velasquez-Valencia A , Dezzeo, Nelda, Flores S, Zambrano-martínez S, Rodgers, Louise \& Ochoa E, Flora D, et al. Hubungan Pengetahuan Dan Sikap Masyarakat Terhadap Tindakan Penanggulangan Penderita Demam Berdarah Dengue (DBD) Di Kelurahan Tanjung Rejo Kecamatan Medan Sunggal. Interciencia. 2018;489(20):313-35.

Sinurat. Karakteristik penderita Demam Berdarah Dengue Yang Di Rawat Inap Di Rumah sakit Santa Elisabeth MedanTahun 2016. 2017;

WHO. No Title. 2016. 
Anindya, Sudarmaja2 IM, I Kadek Swastika3. Karakteristik Penderita Demam Berdarah Dengue (Dbd) Di Rsup Sanglah Bulan Juli - Desember Tahun 2014. E-Jurnal Med. 2018;7(7):1-7.

Rasyada A, Nasrul E, Edward Z. Hubungan Nilai Hematokrit Terhadap Jumlah Trombosit pada Penderita Demam Berdarah Dengue. J Kesehat Andalas. 2014;3(3):343-7.

Ketaren HS. Fakultas kesehatan masyarakat universitas sumatera utara medan 2009. Univ Stuttgart. 2009;

Hidayat WA, Yaswir R, Murni AW. Hubungan Jumlah Trombosit dengan Nilai Hematokrit pada Penderita Demam Berdarah Dengue dengan Manifestasi Perdarahan Spontan di RSUP Dr. M. Djamil Padang. J Kesehat Andalas. 2017;6(2):446.

Cahyani R. Gambaran peran perawat dalam penatalaksanaan asuhan keperawatan pada pasien DBD (Demam Berdarah). 2020; Available from: http://thesis.umy.ac.id/datapublik/t8672.pdf

Nisa N. Karakteristik Demam Berdarah Dengue pada Anak di Rumah Sakit Roemani Semarang. J Kedokt Muhammadiyah [Internet]. 2011;1(2):93-8. Available from: https://jurnal.unimus.ac.id/index.php/kedokteran/article/view/1354

BMKG. Buletin Hujan Bulanan di Indonesia [Internet]. 2020. Available from: https://www.bmkg.go.id/

Wahyuni \& Sabir. Karakteristik Penderita Demam Berdarah Dengue (DBD) di Rumah Sakit Wahidin Sudirohusodo Makassar Periode Januari - Desember 2010. 2011;(Xiv):65-90.

Wila RW, Nusa R. Gambaran Klinis dan Respon Imun Penderita Demam Berdarah Dengue di Rumah Sakit Kristen Lindi Mara Sumba Timur Selama Bulan Januari Sampai dengan Desember 2018. Balaba J Litbang Pengendali Penyakit Bersumber Binatang Banjarnegara. 2020;209-16.

Nasution N, Septia R. Pengelompokan Diagnosis Dan Prosedur Berdasarkan Icd X Dan Icd Ix Di Rsi Siti Rahmah Padang. J Manaj Inf Kesehat Indones. 2020;8(1):53. 